officer of the Steel Structures Research Committee of the Department of Scientific and Industrial Research.

27

Mr. J. S. L. Gilmour

Mr. J. S. LMGrivpon, who has just been appointed director of he Roul Horticultural Society's gardens at Wisley hroween assistant director at the Royal Botark Gardons, Kew, since 1931, although during the War he was seconded to the Ministry of Fuel and Poyfer. While at Kew he showed himself to be an able administrator, and his genuine and assiduous interest in the welfare of the student-gardeners will engender a feeling of personal loss beyond the circle of his immediate colleagues. It is a happy augury for the future of horticulture that the directorships of the Royal Gardens, Kew, and the gardens at Wisley should be thus held by men linked by ties of friendship and common interests. Changing economic conditions must inevitably bring about considerable re-orientation of the pursuits and interests of the fellows of the Royal Horticultural Society and thus influence the purpose and policy of their Gardens, so that our good wishes go out to Mr. Gilmour in his difficult but interesting task.

\section{National Union of Teachers: New General Secretary}

Mr. RONALI Gould has been appointed general secretary of the National Union of Teachers in succession to Sir Frederick Mander, who is to retire in 1947. $\mathrm{Mr}$. Gould was president of the Union during 1943-44. $\mathrm{He}$ is at present headmaster of Welton Council School, Bath, and is a well-known figure in the toaching world. He was educated at Shepton Malyet Grammar School and received his professional training at Westminster College. After leaving college, he was appointed assistant master at Radstock Council School, and while in this area became president of the Radstock Association of the National Union of Teachers, a representative on the County Teachers' Association and Somerset's representative on the Lower Paid Areas' Association Council. He was elected as an executive member of the National Union of Teachers in 1937. He has been a member of the Burnham Committee on Teachers' Salaries since 1938 .

Society for the Protection of Science and Learning

IN 1933 wen the rise of the Nazi party rendered the position of men of science and other scholars extrenerty dangerous, the Academic Assistance Counch was founded to help the refugees; later its titron was changed to the Society for the Protection of Science and Learning. The recently published fifth annual report (issued from Westminster College, Cambridge) surveys the Society's activities for the years 1939-45. These years, being war years, have necessitated the limitation of the survey chiefly to an account of the academic refugees in Great Britain. Of the 2,541 individuals who were registered, only 601 are now in this country. The majority of those who have found employment abroad are in the United States. Some of these are in the special foundations of French and Polish exiled scholars, or on the staff of the School for Social Research in New York. Spanish exiles have found their way to Mexico, and the Central and South American countries have absorbed a large number of the refugees. Others have gone to the
British Dominions, some to Turkey, Palestine, Sweden and Switzerland. Of those in Great Britain, about 40 per cent are in universities and parallel institutions. Another group, about 36 per cent, are employed in some of the professions, industry and the Government service. Scholars of Allied nationality have returned or will return to their own countries if they are Dutch, Belgian, French or Scandinavian, but the Poles and some of the Czechs are in a difficult position. So far as numbers are concerned, the Germans and Austrians present special problems. Some with a good war record have been naturalized; these will presumably remain in Britain, but some definitely wish to return, and discussions are now taking place for the return of some of them to the British zone. The report emphasizes that the Society is not a welfare agency in the usual sense, but exists to make the work of refugee scientific workers and other scholars available, by maintaining them while other support is not forthcoming. It is expected that in a few years time the activities of the Society will be considerably curtailed, but in the meantime much work still remains to be done.

\section{Fifty Years of Danish Marine Biology}

THE interfeption to research caused by the War has been y llized by Dr. Blegvad to produce a lavishly illustrated account, full of interesting personal details, of the first fifty years work of the Danish Biological Stafion (Report Danish Biol. Stat., 45; 1940, publish pd 1944). In 1899 a moored transport vessel was adapted for use as a laboratory under the direction of C. J. Johannes Petersen. A long series of papers published during thirty years shows how much marine biology owes to his energy, ability and originality. Early famous for his invention, still in use, of a method of marking living fish, his bottomsampling grab led to a greatly extended knowledge of animal life of the sea-bottom and of the food available for marketable fish such as plaice. The laboratory has always been closely connected with the University of Copenhagen, while under the late A. C. Johansen and the present director there has developed a friendly and valuable collaboration with the fishermen, who have benefited financially from the experiments on transplantation of young plaice from the North Sea to richer feeding-grounds. Housed now in the beautiful Charlottenlund Castle, with a fine modern aquarium close by and a wellequipped research vessel and motor-boat available, the Station is well qualified to play again an active part in solving regional and international problems of aquatic biology.

\section{Nuclear Energy and its Utilization}

AN address delivered at Cordoba Observatory, Argentina, by E. Gaviole, president of the Argentine Physical ssociation, points out that men of science are spoilly agreed that within five years every majof Industrial country that wishes will possess atcolc bombs, that there is no defence against surprise adolnic aggression and in any such warfaxie both combatants will suffer unparalleled destruction in a few days. Accordingly, the object should be to avoid war ; and nations should surrender a part of their sovereignty to achieve security. Commenting that the scientific workers of the southern hemisphere are in a privileged position and unlikely to be a target, Dr. Gaviole suggests that the fact that governments themselves will be exposed to attack 
may be a factor in avoiding war, but points out that disarmament, by putting a premium on the power that breaks agreements and arms secretly, is dangerous. He questions the practicability of international organisation in the shape of a police force, partly on the grounds of loyalties, and suggests that any international organisation of scientific workers would be rendered futile by these factors of secrecy and national loyalties. While Dr. Gaviola displays the difficulties of the situation, he appears to lose sight altogether of the favourable factors emphasized by the American report on the international control of atomic energy, and a rather depressing and com placent address demonstrates the need of the moral imperative stressed in the report from the Commission appointed by the British Council of Churches.

\section{Training of Demobilized Electrical Engineers}

Among the various questions considered at a recent meeting of the Electrical Engineering Committee of the Technićal and Scientific Register were proposals for securing employment for men who joined the technieal branches of the Forces immediately on gradúation and are now being demobilized. They hate not previously had industrial experience, but many have had the advantage of commissioned service in technical corps and have shown qualities of leadership and initiative which should be of great value to industry. Suggestions made by the Committee are likely to lead to experimental schemes of training in industrial concerns with the view of preparing these ex-Service personnel for responsible posts after training. The Committee realizes that adequate pay arrangements will be required in order to make training schemes of this kind economically practicable. The Committee stressed the importance of developing still further the close co-operation which already exists between the Ministry of Labour's Technical and Scientific Register and the Professional Engineers Appointments Bureau, and expressed the hope that industry generally would make use to the fullest possible extent of the facilities offered by the Register. The Committee also considered a detailed report of the work of the Electrical Engineering Section of the Register.

\section{Luccock Medical Research Fellowships}

THe Luccock Fellowships have been established by King's College, University of Durham, as a result of the bequest of the late Mr. J. W. Luccock, who left his mong "to enable research to be made and carried on as the component parts of the blood of human beings with the view and in the hope that such research investigation and enquiry will be of benefit th the human race and increase the knowledge of the medical and surgical profession as to all matters relating to the blood which may result in the alleviation of human suffering and probably the prolongation of life". Fellows elected will be required to pursue full-time research in the University of Durham in an approved subject in the field of medicine (including dental surgery). Senior fellowships are of the minimum annual value of $£ 600$ and are open to any person who by publication or otherwise has proved himself able to carry out original research in the field of medicine (including dental surgery) and are tenable for three years. Junior fellowships are of the minimum annual value of $£ 300$ and are open to any person holding medical, dental or scientific qualifications, and are tenable for one year. Supple- mentary grants in aid of the expenses of the research may be sanctioned by the Council of the College, and any apparatus purchased by these means will remain the property of the College.

\section{Spitfire Mitchell Memorial Scholarships}

As a memorial to the work of Mr. R. J. Mitchell, designer of the Spitfire, two Spitfire Mitchell Scholarships have been founded to train students in aircraft design and engineering. These Scholarships will be


be tenable at University College, Southampton. Applications should be made to the Registrar, University College, Southampton, not later than August 12, and should be accompanied by a statement of the candidate's education and experience, and a recommendation from his employer or headmaster, together with the candidate's own age, which must be more than seventeen. The awards are in the hands of the Royal Aeronautical Society, the Society of British Aireraft Constructors, Messrs. VickersArmstrongs, Ltd., and the Committee of the Spitfire Mitchell Memorial Fund.

\section{Announcements}

Prof. Lrgs Meitner will deliver a public lecture on "Atongic Energy" at Chatham House, St. James's Squares S.W.1, on July 30 at 8 p.m. Admission is free 65 ticket obtainable from the British Federation of University Women Ltd., 17a Kings Road, London, S.W.3.

Mr. Horade Cole has been appointed lecturer in the chemistry of glass in the University of Sheffield. The following resignations have been announced: Dr. Andrew Wilson, lecturer in pharmacology and tbrapeutics; Dr. J. Dick, lecturer in mechanical engineering; Dr. J. H. Hale, assistant bacteriologist and demonstrator.

Mr. CXRIL BIBBy, at present education officer to the Contral Council for Health Education, is resigning that post on his appointment as senior lecturer at the College of St. Mark and St. John, Chelsea, London.

As one method of meeting the demand for chemical engineers which modern industrial development is creating and increasing, the Ministry of Education is arraxging for full-time intensive training courses in a Aumber of technical colleges (see Nature, July 6, p. 20). The courses will last for approximately twelve months, and will be recognized by and operated in co-operation with the Institution of Chemical Engineers. Applications for further information (Leaflet P.L. 216) should be addressed to the Ministry of Labour and National Service, Technical and Scientific Register, York House, Kingsway, London, W.C.2.

IN furtherance of its policy of promoting the study of textily technology, the Textile Institute is now offering two scholarships for students, each of three years tenure and of total value $£ 750$. The scholarships are offered under the terms of a grant from the Gotton Trade War Memorial Fund, and young craftsmen engaged in the cotton spinning or weaving industry are eligible. Forms of application, conditions and other information are available from the General Secretary, Textile Institute, 16 St. Mary's Parsonage, Manchester 3. Applications must be made by August 3. 